\title{
Institutional Review Board Independent Ethics Committee Subject Information Document
}

National Cancer Institute

\section{Source}

National Cancer Institute. Institutional Review Board Independent Ethics Committee

Subject Information Document. NCI Thesaurus. Code C115700.

Records approved by the Institutional Review Board (IRB)/Independent Ethics Committee

(IEC) that provides a subject with information about a clinical trial. 